\title{
IGF-independent effects of IGFBP-2 on the human breast cancer cell line Hs578T
}

\author{
Klaus W Frommer, Katharina Reichenmiller ${ }^{1}$, Burkhardt S Schutt, Andreas Hoeflich ${ }^{2}$, \\ Michael B Ranke, Gabriele Dodt ${ }^{3}$ and Martin W Elmlinger
}

\author{
Pediatric Endocrinology Section, University Children's Hospital, 72076 Tuebingen, Germany \\ ${ }^{1}$ School of Dental Medicine at the University of Tuebingen, Department of Conservative Dentistry, 72076 Tuebingen, Germany \\ ${ }^{2}$ Institute of Molecular Animal Breeding and Biotechnology/Gene Center, Ludwig-Maximilians-University, 81377 Munich, Germany \\ ${ }^{3}$ Institute for Biochemistry, Department of Cell Biochemistry, Eberhard-Karls-University, 72076 Tuebingen, Germany
}

(Requests for offprints should be addressed to M W Elmlinger; Email: martin.elmlinger@altanapharma.com)

\begin{abstract}
There is evidence that insulin-like growth factor-binding protein (IGFBP-2), a modulator of the actions of IGFs, also has IGF-independent effects in human tumor cell lines. These involve specific binding of IGFBP-2 to $\alpha 5 \beta 1$-integrin, followed by alterations in the phosphorylation status of downstream signaling molecules. Previously, IGFBP-2 has also been shown to be associated with cell proliferation, adhesion and migration. Here, we investigated direct effects of IGFBP-2 on apoptosis and alterations in the expression of related proteins. The breast cancer cell line Hs578T, which shows no IGFBP-2 production of its own and is independent of the IGF-I receptor, was treated with human recombinant IGFBP-2 in order to study the changes in gene expression induced by IGFBP-2. The methods employed for this purpose were oligonucleotide microarrays, real-time RT-PCR, western blotting, and immunoassays. Out of the 440 genes covered by the Oligo GEArray Human Cancer Microarray OHS-802, the expression of 77 genes was directly influenced by IGFBP-2. By the use of real-time quantitative RT-PCR, the gene expression of Nuclear Factor (NF) $\kappa B$, p53, transforming growth factor $\beta$ (TGF $\beta-1$ ), LAMB1 (Laminin, Beta 1), Bcl-2, and IIp45 was found to be significantly upregulated (by $1 \cdot 2-$ to $3 \cdot 05-$ fold; all $P<0.001$ ). Accordingly, NFKB, p53, and TGF $\beta-1$ proteins, as measured by Western blotting and immunoassay, were upregulated $>1 \cdot 5$-fold. By using an ELISA-based and a flow cytometry-based apoptosis assay, IGFBP-2 was found to have a pro-apoptotic effect on Hs578T cells. Our results suggest that IGFBP-2-induced gene expressions are of functional significance for proliferation, cell adhesion, cell migration and apoptosis, and showed that IGFBP-2 can promote apoptosis in tumor cells independent of IGF.
\end{abstract}

Journal of Molecular Endocrinology (2006) 37, 13-23

\section{Introduction}

As part of the insulin-like growth factor (IGF) system, the IGF-binding proteins (IGFBPs) play an important role in the regulation of a multitude of cellular processes (Clemmons 1997, Firth \& Baxter 2002). IGFBP-2, the second most frequent IGFBP in the human circulation, is involved in many physiological and pathological conditions and processes: IGFBP-2 is highly expressed during the perinatal period (Blum et al. 1993, Lindenbergh-Kortleve et al. 1997), while in adults the highest concentrations of IGFBP-2 are found in cerebrospinal fluid (Binoux et al. 1991, Arnold et al. 1999), mother's milk (Elmlinger et al. 1999) and seminal plasma (Rosenfeld et al. 1990). IGFBP-2 is also often highly expressed in malignant tumor cells but decreases upon remission (Muller et al. 1994,
Elmlinger et al. 1996, Hoeflich et al. 2000, Elmlinger et al. 2001, Moore et al. 2003, Ranke et al. 2003). The elevated expression is reflected by elevated serum concentrations of IGFBP-2 in tumor patients, which is often correlated with tumor malignancy (Boulle $e t$ al. 2001, Elmlinger et al. 2001, Baron-Hay et al. 2004). This makes IGFBP-2 a potential progression-dependent tumor biomarker and suggests a functional role for IGFBP-2 in tumor progression.

IGFBP-2 possesses multiple biological functions beyond the modulation of IGF activity through sequestration of IGFs (Hoeflich et al. 2001a). These, for example, include the regulation of GH-stimulated growth (Hoeflich et al. 2001b, Eckstein et al. 2002), of proliferation and both cell adhesion and migration (Hoeflich et al. 1998, Schutt et al. 2004). This has been demonstrated by studies on human cell culture models 
as well as animals. IGFBP-2 actions themselves have been shown to be modulated by limited proteolysis of IGFBP-2 resulting in fragments with specific activities and/or affinities. In particular, limited proteolysis of IGFBP-2 could be induced by plasminogen (Menouny et al. 1997), basic fibroblast growth factor (Russo et al. 1999), and retinoic acid (Bernardini et al. 1994, Chambery et al. 1998).

As pointed out above, IGFBP-2 has a multitude of effects, which can be mediated either by its IGF-dependent or by its IGF-independent actions. IGF-dependent actions are considered to be due to any type of modulation of IGF activity, whereas IGF-independent actions are those mediated by other mechanisms in which IGFs are not involved. The identification of possible pathways through which IGFBP-2 can act IGF-independently has shed new light on the cellular functioning of this protein. To date, there is evidence that IGFBP-2 can initiate cellular signaling through specific binding of its RGD-motif to integrin receptors, e.g. $\alpha 5 \beta 1$ (Schutt et al. 2004), and modulate IGF and epidermal growth factor signaling through bimolecular interactions with $\alpha v \beta 3$ integrins (Pereira et al. 2004). As a second pathway, IGFBP-2 has also been shown to bind to glycosaminoglycans, heparin, and proteoglycans (Arai et al. 1996, Russo et al. 1997, Conover \& Khosla 2003), amongst others, by means of its heparinbinding domain (Russo et al. 2005). In addition, IGFBP-2 was found to be localized on the cell surface (Pereira et al. 2004, Schutt et al. 2004, Russo et al. 2005), in the cytoplasm, on the nuclear surface (Hoeflich et al. 2004) and even within the nucleus (Terrien et al. 2005).

While the regulation of proliferation, cell migration and adhesion could at least in part be ascribed to IGFindependent signaling through integrin receptors (Schutt et al. 2004), IGF-independent effects of IGF BP-2 on apoptosis have not been studied in detail so far.

One possible approach towards the identification of IGF-I-independent pathways of IGFBP-2 actions involves the human breast cancer cell line Hs578T, which possesses no functional IGF-I receptor, thereby excluding IGF-I-dependent effects (De Leon et al. 1992, Gill et al. 1997). By adding human recombinant IGF BP-2 to this cell line, which produces no IGFBP-2 on its own, we studied the effects of IGFBP-2 on gene expression with special interest in apoptosis-related genes and proteins.

Expression studies were performed on mRNA and protein level using oligonucleotide microarray analysis, real-time RT-PCR, Western immunoblotting, and an immunoassay. To study the effect of IGFBP-2 on apoptosis, the apoptotic status of the Hs578T cell cultures was determined with two different cell deathdetection assays.

\section{Materials and methods}

\section{Cell culture}

The breast cancer cell line Hs578T was purchased from the European Collection of Cell Cultures (No. 86082104 ECACC, Porton Down, Salisbury, UK) and cultured in DMEM:F12 (1:1) + GlutaMAX I supplemented with HEPES $(12.5 \mathrm{mM})$ and $10 \%$ fetal bovine serum in a humidified incubator at $37^{\circ} \mathrm{C}$ and $5 \% \mathrm{CO}_{2}$. Unless indicated otherwise, all reagents and media used for cell culture were obtained from GIBCO Invitrogen, Karlsruhe, Germany. Hs578T cells were grown up to $\sim 70 \%$ confluency, the standard medium was replaced by serum-free medium 24 hours before harvesting, and equal numbers of cell cultures were left either untreated or were treated with $2000 \mathrm{ng} / \mathrm{ml}$ IGFBP-2, overnight. Cells $\left(0.5 \times 10^{6}\right)$ were seeded into T25 polystyrene culture flasks (BD Biosciences Discovery Labware, Heidelberg, Germany) for mRNA isolation and $100 \times 20 \mathrm{~mm}$ polystyrene culture dishes (BD Biosciences Discovery Labware) for producing protein lysates. Cells were detached using TrypsinEDTA (1X) and counted with the Advia 120 cell counter (Bayer, Leverkusen, Germany).

\section{Microarray expression analysis}

mRNA from Hs578T cells treated with $2000 \mathrm{ng} / \mathrm{ml}$ IGFBP-2 and untreated Hs578T cells were isolated with the ArrayGrade mRNA purification kit (Superarray, Frederick, USA). Using the TrueLabeling-AMP Linear RNA amplification kit (Superarray), the mRNA was reversely transcribed to obtain cDNA and converted into biotin-labeled cRNA using biotin-16-UTP (Roche, Mannheim, Germany) by in vitro transcription. Prior to hybridization, the cRNA probes were purified with the ArrayGrade cRNA cleanup kit (Superarray). The purified cRNA probes were then hybridized to the pretreated Oligo GEArray Human Cancer Microarrays OHS-802 (Superarray), which cover 440 cancer-related genes. Following several washing steps, array spots binding cRNA were detected using alkaline phosphatase-conjugated streptavidin and CDP-Star as chemiluminescent substrate. Chemiluminescence was detected with the Raytest CCD camera system DIANA II (Raytest, Straubenhardt, Germany). The image data were transformed into numerical data using a software called ScanAlyze v2.50 (http://rana.lbl.gov/EisenSoftware. $\mathrm{htm})$. The numerical data were then further evaluated with Microsoft Excel 97. Data evaluation included background correction (subtraction of minimum value) and median normalization. Data filtering criteria were as follows: at least one of the spot intensities to be compared had to be more than twice the background intensity, and the spot intensity ratios had to be higher 
than 1.5 (for upregulation) or lower than -1.5 (for downregulation).

\section{Real-time RT-PCR}

Total RNA was isolated from Hs578T cells with the RNeasy mini kit (Qiagen, Hilden, Germany) and was used for real-time quantitative RT-PCR. In order to compensate for biological variations, RNA samples from six cultures grown in parallel were pooled for IGFBP-2 treated and untreated Hs578T cells, respectively. The pooled RNA samples were reversely transcribed using the Omniscript kit (Qiagen) according to the manufacturer's instructions. An oligo-dT primer was used for priming the reverse transcription. $\beta_{2}$-Microglobulin (B2M) was chosen as the reference gene for normalization of the results. Technical variations were compensated by running 12 parallel reactions for each cDNA sample pool. The real-time PCR was performed in a Bio-Rad iCycler using SYBR Green I as the detection system (iQ SYBR Green Supermix; Bio-Rad, Munich, Germany). The results were analyzed with the Bio-Rad iCycler Software 3.0 and Microsoft Excel 97. PCR primers were designed using Primer3 at the Whitehead Institute for Biomedical Research (http://frodo.wi.mit.edu/cgi-bin/primer3/ primer3.cgi) under consideration of the special design criteria for real-time PCR primers. The PCR products were analyzed by melt curve analysis and agarose gel electrophoresis to determine product size and to confirm that no by-products were formed.

\section{Preparation of cell lysates and determination of protein concentration}

Cell lysates were prepared by directly adding $500 \mu \mathrm{l}$ lysis buffer $(10 \mathrm{mM}$ Tris-HCl, $5 \mathrm{mM}$ EDTA, $50 \mathrm{mM} \mathrm{NaCl}$, $30 \mathrm{mM} \mathrm{Na}{ }_{4} \mathrm{P}_{2} \mathrm{O}_{7} \cdot 10 \mathrm{H}_{2} \mathrm{O}, 50 \mathrm{mM} \mathrm{NaF}, 1 \%$ (w/v) Triton $\mathrm{X}-100,1 \mathrm{mM}$ phenylmethylsulfonyl fluoride, complete mini EDTA-free protease inhibitor cocktail (Roche, Mannheim, Germany), $\mathrm{pH} 7 \cdot 6$ ) onto the cell cultures previously washed with PBS. After 15 min incubation on ice, the lysed cells were scraped off, triturated, and transferred to $1.5 \mathrm{ml}$ polypropylene tubes. Insoluble cell debris was removed by centrifugation $(20000 \mathrm{~g}$, $20 \mathrm{~min}, 4^{\circ} \mathrm{C}$ ). Protein concentrations were determined photometrically using the commercial BCA-200 Protein assay kit (Pierce, Rockford, IL, USA).

\section{Western immunoblot analysis}

Soluble fractions of the cell lysates were separated on a $6 \%$ stacking/12\% separating SDS-polyacrylamide gel for approximately $2 \mathrm{~h}$ at $200 \mathrm{~V}$. The separated proteins were then blotted onto a PVDF membrane $(0.45 \mu \mathrm{m}$;
Millipore, Schwalbach, Germany) at $1 \mathrm{~mA} / \mathrm{cm}^{2}$ by a semi-dry blotting procedure (Trans-Blot SD Semi-Dry Transfer Cell; Bio-Rad) using CAPS (3-(cyclohexylamino)-1-propane sulfonic acid) buffer (10 mM CAPS, $0.005 \%$ SDS, $10 \%$ methanol, pH $11 \cdot 0$ ). After blocking for $1 \mathrm{~h}$ in TBS-T $(0.01 \mathrm{M}$ Tris, $0 \cdot 15 \mathrm{M} \mathrm{NaCl}, 0 \cdot 1 \%$ Tween-20, pH 7.6) containing 10\% Rotiblock (Roth, Karlsruhe, Germany), the blots were incubated with either p53 or nuclear factor (NF) $\mathrm{B}$ p105/p50 primary antibody (all 1:4000 in TBS-T, 10\% (v/v) Rotiblock) overnight at $4^{\circ} \mathrm{C}$ (both antibodies were from Cell Signaling Technology, Beverly, MA, USA). After washing the membranes three times for 15 min with TBS-T, the blots were incubated for $2 \mathrm{~h}$ in secondary antibody conjugated to horseradish peroxidase (anti-rabbit IgG, HRP-linked antibody; Cell Signaling Technology) diluted 1:5000 in TBS-T with 10\% (v/v) Rotiblock. This allowed detection of secondary antibody using the ECL Plus chemiluminescence detection kit (Amersham Pharmacia, Freiburg, Germany). The blots were then exposed to Kodak Biomax film for 5 to $10 \mathrm{~min}$ at room temperature. The bands were analyzed densitometrically using the Aida $2 \cdot 1$ software (Raytest). The results are based on 12-16 technical replicates (i.e. individual band densities).

\section{TGF $\beta-1$ immunoassay}

The level of secreted transforming growth factor $\beta-1$ (TGF $\beta-1)$ in cell culture supernatants was measured using a commercial human TGF $\beta$-1 ELISA kit from Anogen (Ontario, Canada). The immunoassay was performed using biological triplicates for samples (Hs578T cell cultures treated with IGFBP-2) and controls (Hs578T cells left untreated). In addition, each biological sample was measured in duplicate. In order to compensate for differences in cell number affecting the amount of secreted TGF $\beta-1$, the cells were counted and the final results are given as mean amount of TGF $\beta-1$ produced per $10^{3}$ cells.

\section{Cell death detection assays}

Both the Cell Death Detection ELISA ${ }^{\text {PLUS }}$ and the Annexin-V-FLUOS staining kit (both from Roche) were used to quantitate apoptosis for IGFBP-2-treated and untreated Hs578T cells respectively. The Cell Death Detection ELISA $^{\text {PLUS }}$ is a photometric enzyme immunoassay for the quantitative in vitro determination of cytoplasmic histone-associated DNA fragments (monoand oligonucleosomes) after induced cell death. In the case of the Cell Death Detection ELISA ${ }^{\text {PLUS }}$, each stimulation and control group consisted of three cell cultures grown in parallel. The resulting samples were then measured in triplicate, so that the overall number of 
replicate measurements for one condition was nine. The relative apoptotic values were corrected for cell numbers. Flow cytometric detection of Annexin-V-labeling of phosphatidylserine was performed on a FACSCalibur flow cytometer (BD Biosciences Immunocytometry Systems, San Jose, CA, USA) using the software CellQuest $3 \cdot 3$ (BD Biosciences). The FACS data were then evaluated with the software WinMDI 2.8 (http://facs.scripps.edu/ software.html). The experiment was performed three times under identical conditions.

In both assays, cell cultures treated with camptothecin served as positive controls.

\section{Statistical analysis}

Replicate measurements were used to calculate arithmetic means and standard errors of the mean (S.E.M). Data are presented as means \pm s.E.M. In order to assess the significance of differences, a two-tailed Student's $t$-test was performed. Differences were considered to be significant for $P<0.05$ (*), $P<0.01$ (**), and $P<0.001$ (***) with increasing degrees of significance. The software used for statistical analysis was Microsoft Excel 97.

\section{Results}

\section{IGFBP-2 regulates the expression of multiple genes at the mRNA level}

In order to test our hypothesis that exposure to IGFBP-2 alone can induce changes in gene expression in the absence of IGF-I, we performed microarray experiments with the IGF-insensitive breast cancer cell line Hs578T. Out of the 440 genes covered by the Oligo GEArray Human Cancer Microarray OHS-802, 77 genes were found to be regulated by IGFBP-2 according to the chosen filter criteria. These genes comprised a variety of ontological groups, most of which could be ascribed to cellular functions such as cell growth or maintenance and cell death, suggesting a functional role of IGFBP-2 in these processes (Table 1).

Genes with relevance for the role of IGFBP-2 in proliferation, cell adhesion and apoptosis were further analyzed by real-time quantitative RT-PCR. NFKB and LAMB1 (laminin, beta 1) were selected from the aforementioned Oligo GEArray Human Cancer Microarray results, while p53 and TGF $\beta-1$ were selected from an Affymetrix microarray analysis (K W Frommer, M W Elmlinger, unpublished observations) performed earlier in our laboratory. Apart from LAMB1, which is involved in cell adhesion, all of these genes are related to apoptosis. Bcl-2 was chosen due to its up-regulation through $\alpha 5 \beta 1$ integrin (Zhang et al. 1995), which is a receptor for IGFBP-2. In addition, IIp45 was more closely investigated because it was recently shown to antagonize IGFBP-2 stimulation of glioma cell invasion by binding IGFBP-2 (Song et al. 2003). To a different extent, all the genes examined showed a highly significant increase in expression $(n=12 ; P<0 \cdot 001)$ (Fig. 1). However, the size of the change in IIp45 expression was so small that its biological significance is rather questionable.

\section{IGFBP-2 regulates NFKB, p53 and TGF $\beta$-1 protein levels}

To determine whether IGFBP-2 addition to Hs578T cells also has a regulatory effect on the protein levels of $\mathrm{NF} \kappa \mathrm{B}$, p53 and TGF $\beta-1$, we performed quantitative Western immunoblot analysis for $\mathrm{NF} \kappa \mathrm{B}$ and $\mathrm{p} 53$ as well as an immunoassay for TGF $\beta$-1. In response to IGFBP-2, $\mathrm{NF} \kappa \mathrm{B}$ and p53 protein levels were found to be upregulated by a factor of $1 \cdot 43 \pm 0 \cdot 11 \quad(n=12$; $P<0 \cdot 001)$ and $1 \cdot 50 \pm 0 \cdot 17(n=16 ; P<0 \cdot 001)$ respectively (Fig. 2). The amount of TGF $\beta-1$ secreted by the Hs578T cells, as normalized by the cell number was increased by a factor of $1.52 \pm 0 \cdot 18(n=9 ; P<0 \cdot 05)$ in response to IGFBP-2 (Fig. 3).

\section{IGFBP-2 has a pro-apoptotic effect on Hs578T breast cancer cells}

Based on the observation that, following exposure to IGFBP-2, the expression of several apoptosis-related genes was significantly altered, we further investigated the immediate effects of IGFBP-2 on apoptosis by two different approaches. The Cell Death Detection ELISA $^{\text {PLUS }}$ and the Annexin-V flow cytometry-based apoptosis assay were employed to determine the occurrence of apoptotic DNA degradation prior to plasma membrane breakdown and the appearance of phosphatidylserine on the outer surface of the plasma membrane. In the presence of IGFBP-2, both assays detected an increase in apoptosis. The Cell Death Detection ELISA ${ }^{\text {PLUS }}$ indicated a $1 \cdot 82$-fold increase $(P<0 \cdot 001)$ of the relative apoptotic values of IGFBP-2 treated versus untreated Hs578T cells (Fig. 4A). Using the Annexin- $\mathrm{V}$ apoptosis assay, we measured a higher percentage of apoptotic cells for Hs578T cells treated with IGFBP-2 as compared with non-treated Hs578T cells. According to this assay, the percentage of apoptotic cells increased on average from $6 \cdot 2 \%$ to $15 \cdot 8 \%$, which corresponds to a ratio of $2 \cdot 6(P<0 \cdot 05)$ (Fig. 4B).

\section{Discussion}

IGFBP-2 has been shown to be involved in a variety of key biological functions such as cell proliferation, migration and adhesion. However, the effects of IGFBP-2 observed in vitro vary depending on the cell lines observed 
Table 1 Selection of functionally classified genes whose expression was induced by IGFBP-2

\begin{tabular}{|c|c|c|c|}
\hline & Gene symbol & $\begin{array}{l}\text { GenBank accession } \\
\text { number }\end{array}$ & Fold cha \\
\hline \multicolumn{4}{|l|}{ Gene name } \\
\hline \multicolumn{4}{|l|}{ Cell proliferation/cell growth } \\
\hline Transforming growth factor, alpha & TGFA & NM_003236.1 & $1 \cdot 81$ \\
\hline Non-metastatic cells 1 , protein expressed in & NME1 & NM 000269.2 & 1.65 \\
\hline stratifin (14-3-3-Sigma) & SFN & NM_006142.2 & $1 \cdot 90$ \\
\hline Tumor protein p73 & TP73 & NM_005427.1 & $2 \cdot 52$ \\
\hline v-yes-1 Yamaguchi Sarcoma viral oncogene homolog 1 & YES1 & NM_005433.2 & $2 \cdot 02$ \\
\hline v-myc myelocytomatosis viral oncogene homolog (Avian) & MYC & NM_002467.2 & $2 \cdot 25$ \\
\hline v-raf-1 murine leukemia viral oncogene homolog 1 & RAF1 & NM_002880 1 & $1 \cdot 74$ \\
\hline DNA-damage-inducible transcript 3 & DDIT3 & NM 004083.3 & $2 \cdot 49$ \\
\hline Polo-like kinase 2 (Drosophila) & PLK2 & NM_006622.1 & $2 \cdot 32$ \\
\hline Retinoblastoma 1 (including osteosarcoma) & RB & NM_000321.1 & $2 \cdot 06$ \\
\hline Tumor susceptibility gene 101 & TSG101 & NM_006292.2 & $1 \cdot 72$ \\
\hline Insulin-like growth factor-binding protein 3 & IGFBP-3 & NM_000598.2 & 1.58 \\
\hline Suppressor of cytokine signaling 1 & SOCS1 & NM_003745.1 & $2 \cdot 15$ \\
\hline Integrin-linked kinase-2 & ILK & NM_004517.1 & $2 \cdot 03$ \\
\hline Cyclin-dependent kinase inhibitor 2B ( $\mathrm{p} 15$, inhibits CDK4) & CDKN2B & NM_004936.2 & $1 \cdot 97$ \\
\hline Proliferating cell nuclear antigen & PCNA & NM_002592.2 & $1 \cdot 72$ \\
\hline Notch homolog 2 (Drosophila) & $\mathrm{NOTCH} 2$ & NM_024408.2 & $2 \cdot 73$ \\
\hline Neurofibromin 2 (bilateral acoustic neuroma) & NF2 & NM_000268.2 & $1 \cdot 90$ \\
\hline Tumor necrosis factor (ligand) superfamily, member 7 & TNFSF7 & NM_001252.2 & $1 \cdot 69$ \\
\hline \multicolumn{4}{|l|}{ Apoptosis/necrosis (cell death) } \\
\hline CD27-binding (siva) protein & SIVA & NM_006427.2 & $1 \cdot 80$ \\
\hline Tumor protein p73 & TP73 & NM_005427.1 & $2 \cdot 52$ \\
\hline Nuclear factor of $\kappa$ light polypep gene enhancer in B-Cells 1 & NFKB1 & NM_003998.2 & $2 \cdot 23$ \\
\hline Tumor necrosis factor (TNF superfamily, member 2) & TNF & NM_000594.2 & $2 \cdot 34$ \\
\hline Tumor necrosis factor receptor superfamily, member 6 & TNFRSF6 & NM_000043.3 & $1 \cdot 65$ \\
\hline Tumor necrosis factor (ligand) superfamily, member 7 & TNFSF7 & NM_001252.2 & $1 \cdot 69$ \\
\hline Tumor necrosis factor receptor superfamily, member $10 a$ & TNFRSF10A & NM_003844.2 & $1 \cdot 71$ \\
\hline v-raf-1 murine leukemia viral oncogene homolog 1 & RAF1 & NM_002880 1 & $1 \cdot 74$ \\
\hline Notch homolog 2 (Drosophila) & $\mathrm{NOTCH} 2$ & NM_024408.2 & $2 \cdot 73$ \\
\hline v-myc myelocytomatosis viral oncogene homolog (Avian) & MYC & NM_002467.2 & $2 \cdot 25$ \\
\hline Non-metastatic cells 3 , protein expressed in & NME3 & NM_002513.2 & $1 \cdot 67$ \\
\hline \multicolumn{4}{|l|}{ Cell adhesion } \\
\hline Laminin, beta 1 & LAMB1 & NM_002291.1 & $2 \cdot 21$ \\
\hline Tissue inhibitor of metalloproteinase 1 & TIMP1 & NM_003254.1 & $2 \cdot 92$ \\
\hline Integrin-linked kinase-2 & ILK & NM_004517.1 & $2 \cdot 03$ \\
\hline Integrin, alpha 3 (antigen CD49C) & ITGA3 & NM_002204.1 & $1 \cdot 84$ \\
\hline Ras-related C3 botulinum toxin substrate 1 & RAC1 & NM_006908.3 & 1.90 \\
\hline
\end{tabular}

This table shows selected results from the oligonucleotide microarray analysis of 440 genes in Hs578T cells treated with $2000 \mathrm{ng} / \mathrm{ml}$ IGFBP-2 relative to untreated controls. It contains the IGFBP-2-induced genes belonging to the ontological groups of proliferation, cell death, and cell adhesion, which were of most interest here because the effects of IGFBP-2 on these cellular processes have previously (Schutt et al. 2004) and are now been studied in our laboratory. From the ontological groups of most interest, genes were selected for which most useful information was available and/or which are more commonly known so that the reader can more easily understand the association of genes with a certain ontological group.

and whether IGFs are involved or not. There have been several theories put forward to explain the positive and negative effects of IGFBP-2. As a carrier of IGFs, IGFBP-2 may increase IGF activity by protecting this growth factor from proteolysis and/or transporting it to the IGF-I receptor (Ranke \& Elmlinger 1997). On the other hand, IGFBP-2 in both soluble and membrane-associated form has been shown to compete with IGFs for their receptor (Reeve et al. 1993), which may reduce IGF effects. The IGF-independent effects are thought to be due mainly to interactions of IGFBP-2 with the extracellular matrix (ECM). Therefore, ECM-connected signal transduction induced by IGFBP-2 interaction with the ECM is very likely
(Schutt et al. 2004, Russo et al. 2005), but also combined signals from the ECM and the IGF-I receptor have to be taken into account.

In order to investigate how IGFBP-2 affects gene expression in vitro in an IGF-independent manner, we treated the IGF-insensitive cell line Hs578T with $2000 \mathrm{ng} / \mathrm{ml}$ human recombinant IGFBP-2. This concentration may appear to be very high compared with normal physiological concentrations. However, serum levels of IGFBP-2 can definitely reach those dimensions. For example, serum IGFBP-2 levels of $1240 \pm$ $270 \mathrm{ng} / \mathrm{ml}$ were measured in patients with Type 1 diabetes (Frystyk et al. 1999). Ovarian cancer patients 


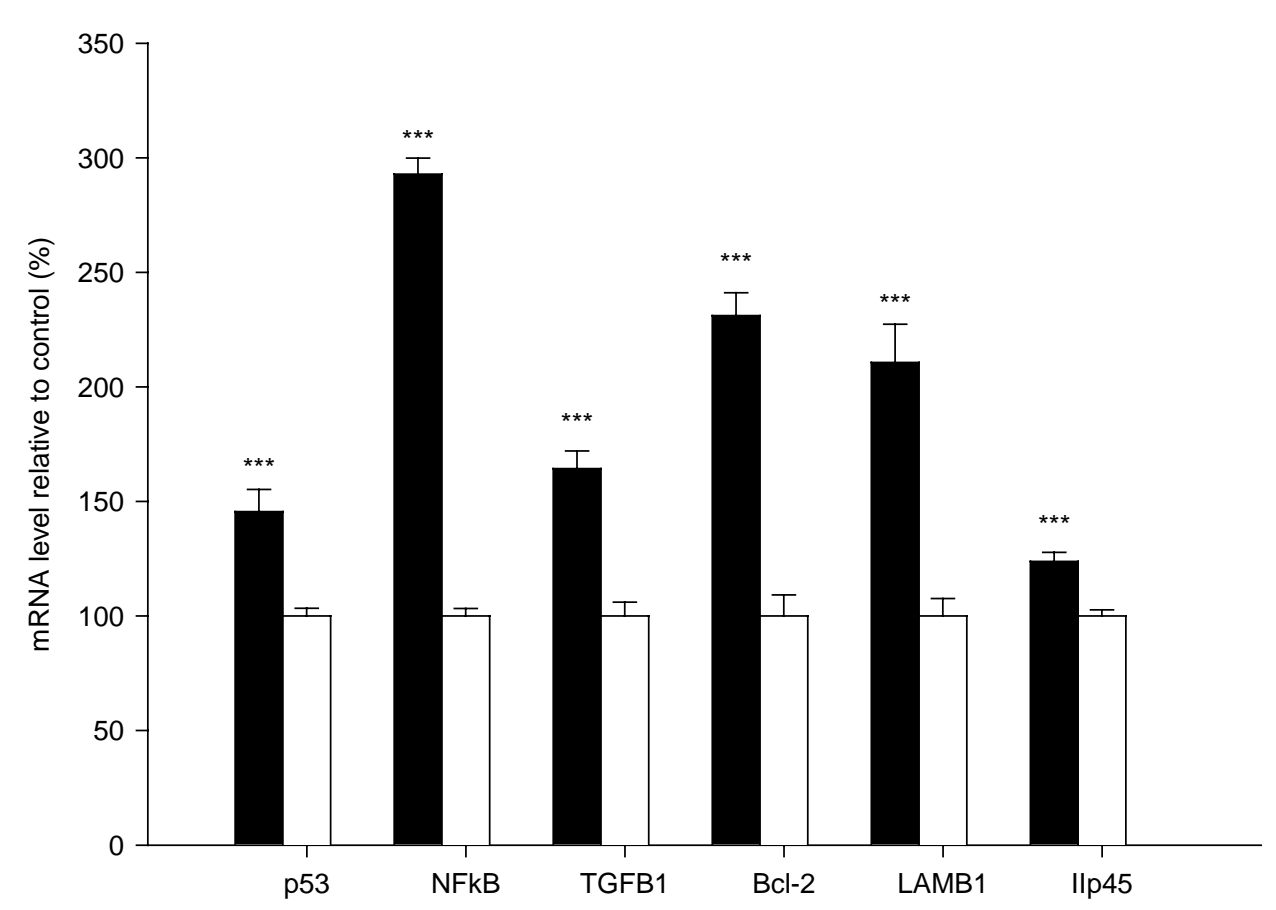

Figure 1 Total RNA was isolated from Hs578T cells treated with IGFBP-2 and from untreated controls. The mRNA was selectively reverse transcribed into cDNA using an oligo-dT primer and was quantitated by real-time PCR in a Bio-Rad iCycler with SYBR Green I as fluorescent dye. The determination of mRNA expression was performed as relative quantification using $\beta 2$-microglobulin as the reference gene for normalization. The mRNA levels are given in percent relative to the control, with the error bars indicating the standard error. Black bars represent mRNA levels in IGFBP-2 treated Hs578T cells, whereas white bars represent mRNA levels in untreated controls. The number of measured replicates for each group and gene was 12 . The differences were all statistically significant $\left(n=12 ;{ }^{\star \star \star} P<0 \cdot 001\right)$.

showed very high serum IGFBP-2 levels of $1773 \pm$ $168 \mathrm{ng} / \mathrm{ml}$ with a range of 841 to $3493 \mathrm{ng} / \mathrm{ml}$ (Flyvbjerg et al. 1997) as measured by RIA. Patients with metastatic adrenocortical tumors had serum IGFBP-2 levels of $1314 \pm 554 \mathrm{ng} / \mathrm{ml}$ (Boulle et al. 2001). There are several other studies which also showed that IGFBP-2 is significantly increased in tumors (Cohen et al. 1993, Kanety et al. 1993, Zumkeller et al. 1993, Muller et al. 1994, Baron-Hay et al. 2004). In addition, with such high serum levels, local concentrations within and around tumors might even be higher. Therefore, concentrations of $2000 \mathrm{ng} / \mathrm{ml}$ IGFBP-2 can actually represent the conditions found with tumors in vivo.

In this study, we were able to identify three sets of genes related to proliferation, migration/adhesion, and apoptosis, which are regulated by IGFBP-2 in our IGF-insensitive breast cancer cell model Hs578T.

\section{IGFBP-2 induction of genes related to proliferation}

The most extensively studied biological end point after IGFBP-2 stimulation is cell proliferation, which nicely exemplifies the opposing effects that IGFBP-2 can have on different cell types. In IGFBP-2 overexpressing Y-1 adrenocortical tumor cells (Hoeflich et al. 2000), A673 Ewing sarcoma cells (Schutt et al. 2004) and SKN-SHEP neuroblastoma cells (Russo et al. 2005), as well as IGF BP-2 treated LAPC-4 prostate cancer cells (Moore et al. 2003), IGFBP-2 is clearly a pro-proliferative factor. In contrast, inhibition of proliferation occurred in IGFBP-2treated fetal podocytes (Bridgewater \& Matsell 2003) and Hs578T breast cancer cells (Schutt et al. 2004), as well as IGFBP-2 overexpressing HEK-293 embryonic kidney cells (Hoeflich et al. 1998). In relation to its proliferative effect, IGFBP-2 has also been found to correlate positively with tumor malignancy, which has been shown in vitro for the previously mentioned Y-1 adrenocortical tumor cells (Hoeflich et al. 2000) and in vivo for human gliomas (Elmlinger et al. 2001). In the present study, we investigated the molecular basis of the previously shown anti-proliferative effects of IGFBP-2 on Hs578T cells (Schutt et al. 2004) by way of identifying changes in the expression of genes known to be involved in proliferation. Since the Hs578T cells under study are IGF-insensitive, the effects of IGFBP-2 are very likely to represent 

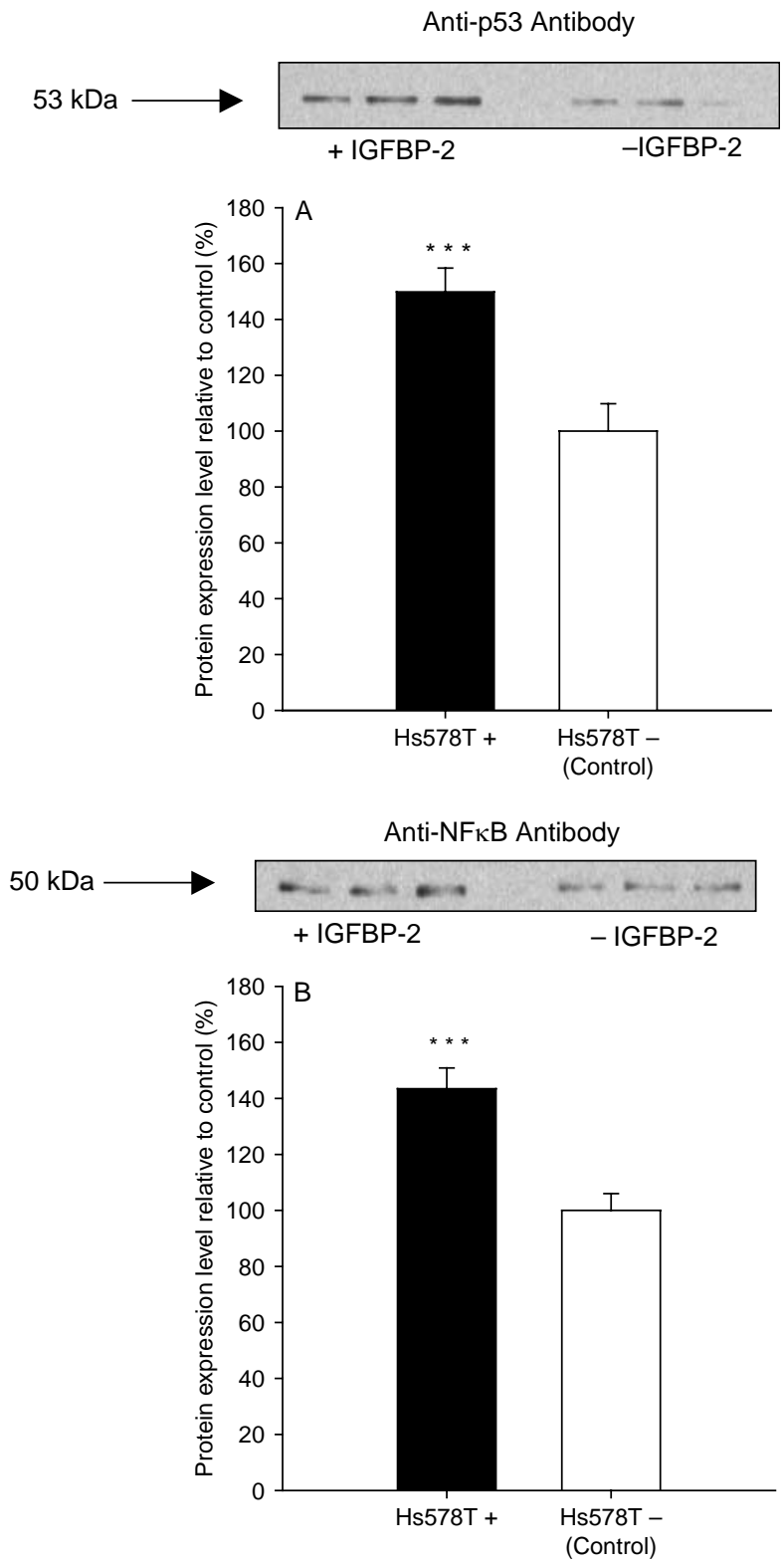

Figure 2 The soluble fractions of Hs578T cell lysates were separated by means of SDS-PAGE. Using a semi-dry blotting procedure, the separated proteins were transferred onto a PVDF membrane. The blots were incubated with either p53 or NF-кB p105/p50 as primary antibody and anti-rabbit IgG conjugated to horseradish peroxidase as secondary antibody. Detection of the secondary antibody was performed with the ECL Plus chemiluminescence detection kit. Finally, the bands were analyzed densitometrically. An exemplary blot is shown for both p53 (A) and $N F \kappa B(B)$. The protein levels are given in percent relative to the control, with the error bars indicating the standard error. Black bars represent protein levels in IGFBP-2-treated Hs578T cells, whereas white bars represent protein levels in untreated controls. The number of replicate bands that were analyzed was 16 for p53 and 12 for NFKB. The differences between treated samples and controls were statistically significant $\left({ }^{\star \star \star} P<0.001\right)$ for both proteins.

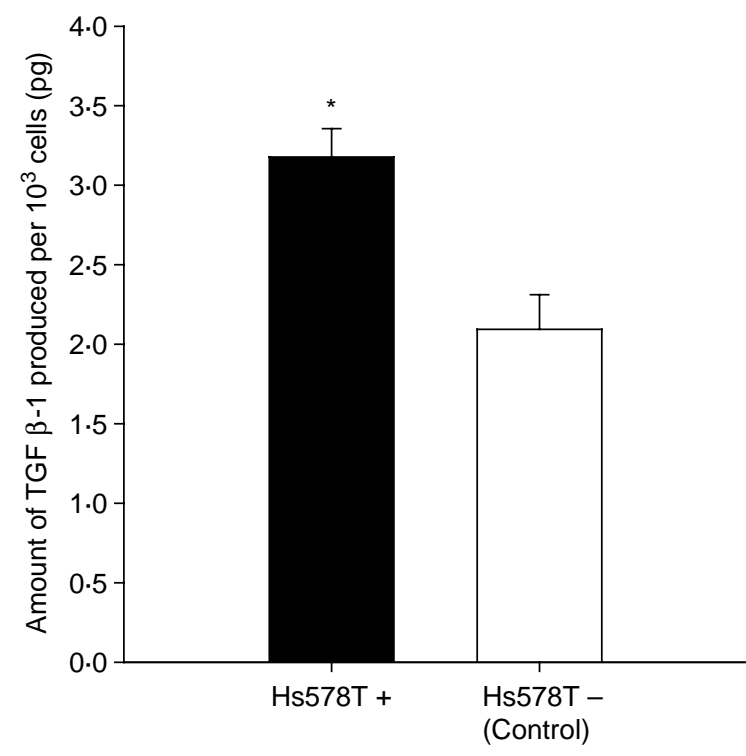

Figure 3 Secreted TGF $\beta$ - 1 levels in cell culture supernatants were quantified using the commercial human TGF $\beta-1$ ELISA kit from Anogen. The results are given as mean amount of TGF $\beta-1$ produced per $10^{3}$ cells. The error bars indicate the standard error. The amount of TGF $\beta-1$ secreted by the Hs578T cells was increased by a factor of $1.52 \pm 0 \cdot 18\left(n=9 ;{ }^{*} P<0.05\right)$ in response to IGFBP-2.

IGF-independent effects of IGFBP-2. In agreement with the above-mentioned anti-proliferative effect of IGFBP-2 on Hs578T cells, we found that IGFBP-2 upregulates the expression levels of TGF $\beta$-1, NME1, SFN (14-3-3-sigma), TP73, RB, TSG101, CDKN2B, NF2, and TNFSF7, all of which represent proteins known to be capable of inhibiting cell proliferation.

\section{IGFBP-2 induction of genes related to migration/adhesion}

Another biological end point that IGFBP-2 is involved in is cell migration and adhesion. It has been shown that cell adhesion was increased in A673 cells and decreased in Hs578T cells (Schutt et al. 2004). Enhanced invasiveness was observed with SKN-SHEP cells (Russo et al. 2005) and SNB19 glioblastoma cells (Wang et al. 2003). In all studied cell models except for Hs578T cells, IGFdependent effects as explained above cannot be excluded, but interaction of IGFBP-2 with the ECM has been proven in these cases. In this study, different genes like ILK (integrin-linked kinase-2), RAC1 (Ras-related C3 botulinum toxin substrate 1), ITGA3 (integrin, alpha 3), TIMP1 (tissue inhibitor of metalloproteinase 1), and LAMB1 were directly or indirectly upregulated by IGFBP-2. These genes are all related to cell adhesion and/or migration, but the interpretation of their regulation is not always straightforward, since the upregulation of some of these genes is not able to 

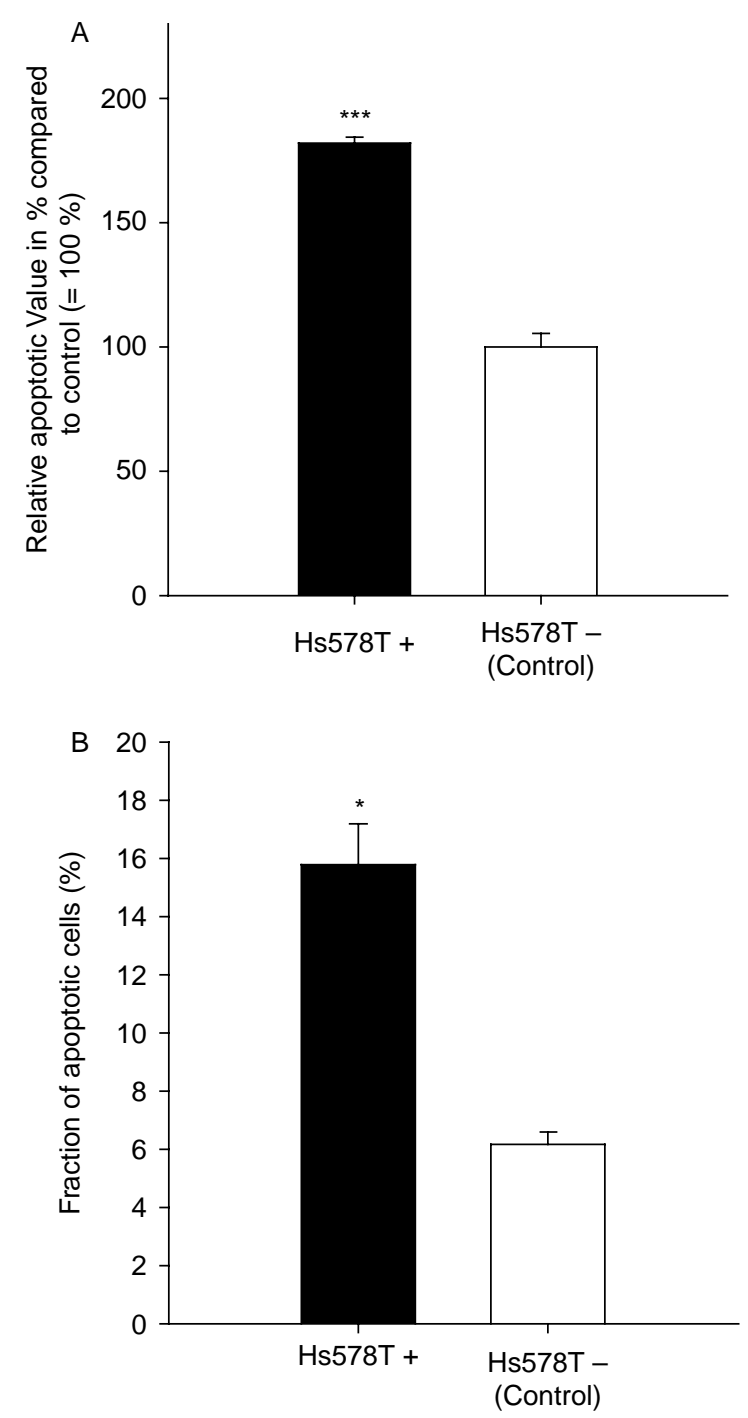

Figure 4 Apoptosis in IGFBP-2-treated (black bars) and untreated (white bars) Hs578T cells was quantitated using the commercial Cell Death Detection ELISA ${ }^{\text {PLUS }}(A)$ and the Annexin-V-FLUOS staining kit (B). Using the Cell Death Detection ELISA ${ }^{\text {PLUS }}$, the relative apoptotic values of IGFBP-2-treated versus untreated Hs578T cells showed a ratio of $1.82\left(n=9 ;{ }^{* \star \star} P<0.001\right)(\mathrm{A})$. Measurements with the Annexin-V-FLUOS staining kit were performed three times under identical conditions. On average, by adding IGFBP-2, the percentage of apoptotic cells increased from $6 \cdot 2 \%$ to $15 \cdot 8 \%(B)$, which corresponds to a ratio of $2 \cdot 6\left(n=9 ;{ }^{*} P<0 \cdot 05\right)$.

directly explain the decrease in adhesion observed previously in the Hs578T cell line (Schutt et al. 2004). In agreement with the observed effects, an upregulation of ILK and RAC1 was found after IGFBP-2 stimulation. ILK is a regulator of integrin-mediated signal transduction and a component of focal adhesions, which are formed upon ligand binding to integrins (Sakai et al. 2003). In the context of adhesion, Hannigan et al. (1996) showed that overexpression of ILK indeed inhibited adhesion to integrin substrates in their epithelial cell model, which, in turn, might explain the decreased adhesion seen after IGFBP-2 treatment of Hs578T cells. RAC1, a GTPase belonging to the RAS family of small GTP-binding proteins, plays a role in the regulation of actin polymerization and in cooperation with CDC42 is able to increase cell motility and invasiveness through an integrin-mediated mechanism (Nobes \& Hall 1995, Keely et al. 1997, Berrier et al. 2002). This corresponds with the enhanced invasiveness observed with SKNSHEP cells (Russo et al. 2005) and SNB19 glioblastoma cells (Wang et al. 2003). The IGFBP-2 upregulated gene ITGA3 encodes the $\alpha 3$ subunit of certain integrin receptors, such as the integrin heterodimer $\alpha 3 \beta 1$, which is a receptor for fibronectin, laminin, collagen, epiligrin, thrombospondin, and CSPG4. Although most integrins are generally associated with an increase in adhesion, it has been found that, in some ITGA3 transfectants, the expression of this integrin $\alpha 3$ subunit resulted in a decrease in cell-cell adhesion (Weitzman et al. 1995). Another observation supporting the antiadhesive effect of the integrin $\alpha 3$ subunit is that $\alpha 3 \beta 1$ integrin is required for the disruption of intercellular adhesion within epithelial cells (Kawano et al. 2001). Deadhesion of cells is certainly not promoted by TIMP, which acts as an inhibitor of specific metalloproteinases. Nonetheless, it appears to be upregulated by IGFBP-2. So its upregulation must be due to a different mechanism. It may be a regulatory cellular response antagonizing the loss of cell adhesion. LAMB1 is a subunit of the heterotrimeric laminin glycoproteins, which are part of the ECM and are able to bind to integrins (Belkin \& Stepp 2000). Amongst others, the laminins play a role in cell adhesion, but the upregulation of LAMB1 does not directly explain the decrease in cell adhesion observed for Hs578T cells. This suggests that the upregulation of LAMB1 may also be a cellular counter response against excessive loss of cell adhesion.

\section{IGFBP-2 induction of genes related to apoptosis}

Finally, our study revealed that IGFBP-2 is directly involved in apoptosis, which - to our knowledge - has not been shown before. However, IGFBP-2 has been shown to positively correlate with another conceptually related process that limits a cell's lifetime: senescence. Several in vitro studies showed a marked upregulation of IGFBP-2 in correlation with replicative senescence using quantitative Northern and microarray analyses (Hjelmeland et al. 1999, Matsunaga et al. 1999, Shelton et al. 1999). The genes SIVA, TP73, TNF, TNFRSF6, TNFSF7, TNFRSF10A, NOTCH2, MYC, NME3, 14-3-3sigma, $\mathrm{NF \kappa B}$, TGF $\beta-1$, and p53 found to be upregulated after stimulation of the Hs578T cells with IGFBP-2 are all known to have pro-apoptotic effects. In agreement with these gene-array data, we were able to confirm 
a pro-apoptotic impact of IGFBP-2 on the Hs578T cells by applying two different apoptosis assays. Some of the regulated genes appear to be part of a regulatory network. 14-3-3-sigma, for example, has a positive feedback effect on p53 activity (Yang et al. 2003). MYC affects the outcome of a p53 response in favor of apoptosis (Seoane et al. 2002). ILK (Li et al. 2003) as well as CDKN2B (p15INK4B) (Hannon \& Beach 1994) have been shown to be a part of the pro-apoptotic response of cells exerted by TGF- $\beta$, which itself is upregulated by IGFBP-2 stimulation. SIVA, a pro-apoptotic protein, binds to TNFSF7 (CD27), through which it is believed to exert its effect on apoptosis (Prasad et al. 1997). The upregulation of the transcription factor $\mathrm{NF \kappa B}$ in response to IGFBP-2 stimulation can also be related to the pro-apoptotic response seen in our cell model, since it has been observed in different studies that $\mathrm{NF} \kappa \mathrm{B}$ is not only involved in anti-apoptotic effects or in the counterbalancing of pro-apoptotic stimuli (Van Antwerp et al. 1996, Mayo et al. 1997) but that NFKB activity is also required for the development of pro-apoptotic activity of p53 (Ryan et al. 2000). Interestingly, the NF $\kappa B$ upregulation can result in an autocrine loop, since the promoter region of IGFBP-2 possesses four distinct positions that can putatively bind $\mathrm{NF} \kappa \mathrm{B}$, which would suggest IGFBP-2 promoter activation (Cazals et al. 1999).

Although the IGF insensitivity of the Hs578T cell model studied here excludes IGF-dependent effects, the exact mechanism by which IGFBP-2 induces the genes involved in proliferation, migration/adhesion and apoptosis found in the present study has not been determined yet. According to the data available in the literature, various interactions of IGFBP-2 with the ECM of the target cell might account for the effects seen after stimulation with IGFBP-2. So far, a direct binding to integrin receptors (Pereira et al. 2004, Schutt $e t$ al. 2004) and resulting cell signaling via the RGD motif of IGFBP-2 (Schutt et al. 2004) as well as binding to glycosaminoglycans, heparin, and proteoglycans (Arai et al. 1996, Russo et al. 1997, Conover \& Khosla 2003) have been observed. Not only proliferation or migration but also apoptosis is known to be induced by integrin signaling and, like IGFBP-1 (Perks et al. 1999), IGFBP-2 might induce apoptosis through dephosphorylation of focal adhesion kinase and the downstream MAPK pathway (Schutt et al. 2004). By using different IGFBP-2 mutants, a direct role of the heparin-binding domain of IGFBP-2 on proliferation and migration has been demonstrated in a recent study (Russo et al. 2005). Therefore, different signaling events mediated by the $\alpha 5 \beta 1$ integrin binding site (i.e. RGD motif), the heparin-binding domain and possibly other yet unknown ECM binding sites of IGFBP-2 might be responsible for the IGF-independent gene induction seen in this study. In addition, IGFBP-2 is able to bind different components of the ECM such as vitronectin, laminin, collagens, and fibronectin (Russo et al. 2005).
So, it is reasonable to assume that there other alternative mechanisms of IGFBP-2 action, like modulation of the dynamics of the reservoir of ECM components and ECM associated proteins; even IGFBP-2 as an integrin ligand competitor acting through binding of other integrin ligands is conceivable (Russo et al. 2005). Besides the explanations for direct IGFBP-2-induced cell responses, further possible mechanisms must be taken into account for IGF-responsive cells. Here, ECM-associated IGFBP-2 can act as a competitor for the IGF-I receptor (Pereira et al. 2004), or the association of IGFBP-2 with the ECM itself may function as a cell targeting mechanism for IGFs. However, the findings that IGFBP-2 was also localized in the cytoplasm and on the nuclear surface (Hoeflich et al. 2004) and interacts with the intracellular cell cycle inhibitor p21CIP1/WAF1 (Terrien et al. 2005) show that IGFBP-2 exerts some of its actions directly within the cell. IGFBP-2 appears to have varying effects on different cell lines. Possible explanations are certainly based on the fact that every cell type has its own specifically composed ECM and expression profile. The gene expression patterns can also considerably differ depending on whether cells are malignant or nonmalignant. Differences in gene expression can, amongst others, involve other IGFBPs or IGFBP proteases, which then affects limited IGFBP proteolysis. With different cellular components, there can be different interactions of IGBFP-2 with other molecules and different signaling pathways that can be induced. Last but not least, the type of administration, i.e. whether IGFBP-2 is overexpressed intracellularly or added externally, may also influence the effect that IGFBP-2 exerts on a certain cell type.

Our results suggest that IGFBP-2-induced gene expressions are of functional significance for proliferation, cell adhesion, cell migration and apoptosis. It might be concluded from our data regarding apoptosis that blockade of IGFBP-2 as a strategy to block tumor growth as suggested previously might - at least in certain cell types - represent a fatal error. The data presented here shed a new light on the biological consequences of locally produced IGFBP-2 as an IGF-independent modulator of proliferation, migration/adhesion and apoptosis. Certainly, however, further studies aimed at the dissection of the different IGFBP-2-mediated effects by its interaction with or modulation of the ECM via its integrin-binding domain, its heparin-binding domain, or even by its ability to bind and possibly target IGFs to the ECM are necessary to fully understand the mode of action of IGFBP-2.

\section{Acknowledgements}

We wish to thank Christian Klein for his help with realtime PCR, Nadine Kemmler for her help with flow cytometry, and Karin Weber for her technical assistance. 
The work was supported by a grant from the German Research Council (DFG EL 167/3-2 and RE 1562/1-2, SPP 1117) and by the Growth Research Center (Pfizer). The authors declare that there is no conflict of interest that would prejudice the impartiality of this scientific work.

\section{References}

Arai T, Busby W Jr \& Clemmons DR 1996 Binding of insulin-like growth factor (IGF) I or II to IGF-binding protein-2 enables it to bind to heparin and extracellular matrix. Endocrinology 137 $4571-4575$.

Arnold PM, Ma JY, Citron BA \& Festoff BW 1999 Insulin-like growth factor binding proteins in cerebrospinal fluid during human development and aging. Biochemical and Biophysical Research Communications 264 652-656.

Baron-Hay S, Boyle F, Ferrier A \& Scott C 2004 Elevated serum insulinlike growth factor binding protein-2 as a prognostic marker in patients with ovarian cancer. Clinical Cancer Research 10 1796-1806.

Belkin AM \& Stepp MA 2000 Integrins as receptors for laminins. Microscopy Research and Technique 51 280-301.

Bernardini S, Cianfarani S, Spagnoli A, Annicchiarico-Petruzzelli M, Melino G, Massoud R, Boscherini B, Finazzi-Agro A, Rosenfeld RG \& Federici G 1994 Expression and down-regulation by retinoic acid of IGF binding protein-2 and -4 in medium from human neuroblastoma cells. Journal of Neuroendocrinology 6 409-413.

Berrier AL, Martinez R, Bokoch GM \& LaFlamme SE 2002 The integrin beta tail is required and sufficient to regulate adhesion signaling to Rac1. Journal of Cell Science 115 4285-4291.

Binoux M, Roghani M, Hossenlopp P \& Whitechurch O 1991 Cerebrospinal IGF binding proteins: isolation and characterization. Advances in Experimental Medicine and Biology 293 161-170.

Blum WF, Horn N, Kratzsch J, Jorgensen JO, Juul A, Teale D, Mohnike K \& Ranke MB 1993 Clinical studies of IGFBP-2 by radioimmunoassay. Growth Regulation 3 100-104.

Boulle N, Baudin E, Gicquel C, Logie A, Bertherat J, Penfornis A, Bertagna X, Luton JP, Schlumberger M \& Le Bouc Y 2001 Evaluation of plasma insulin-like growth factor binding protein-2 as a marker for adrenocortical tumors. European Journal of Endocrinology 144 29-36.

Bridgewater DJ \& Matsell DG 2003 Insulin-like growth factor binding protein-2 modulates podocyte mitogenesis. Pediatric Nephrology 18 1109-1115.

Cazals V, Nabeyrat E, Corroyer S, de Keyzer Y \& Clement A 1999 Role for NF-kappa B in mediating the effects of hyperoxia on IGFbinding protein 2 promoter activity in lung alveolar epithelial cells. Biochimica et Biophysica Acta 1448 349-362.

Chambery D, de Galle B \& Babajko S 1998 Retinoic acid stimulates IGF binding protein (IGFBP)-6 and depresses IGFBP-2 and IGFBP-4 in SK-N-SH human neuroblastoma cells. Journal of Endocrinology 159 227-232.

Clemmons DR 1997 Insulin-like growth factor binding proteins and their role in controlling IGF actions. Cytokine and Growth Factor Reviews 8 45-62.

Cohen P, Peehl DM, Stamey TA, Wilson KF, Clemmons DR \& Rosenfeld RG 1993 Elevated levels of insulin-like growth factorbinding protein-2 in the serum of prostate cancer patients. Journal of Clinical Endocrinology and Metabolism 76 1031-1035.

Conover CA \& Khosla S 2003 Role of extracellular matrix in insulinlike growth factor (IGF) binding protein-2 regulation of IGF-II action in normal human osteoblasts. Growth Hormone and IGF Research 13 328-335.
De Leon DD, Wilson DM, Powers M \& Rosenfeld RG 1992 Effects of insulin-like growth factors (IGFs) and IGF receptor antibodies on the proliferation of human breast cancer cells. Growth Factors 6 327-336.

Eckstein F, Pavicic T, Nedbal S, Schmidt C, Wehr U, Rambeck W, Wolf E \& Hoeflich A 2002 Insulin-like growth factor-binding protein-2 (IGFBP-2) overexpression negatively regulates bone size and mass, but not density, in the absence and presence of growth hormone/ IGF-I excess in transgenic mice. Anatomy and Embryology 206 $139-148$.

Elmlinger MW, Wimmer K, Biemer E, Blum WF, Ranke MB \& Dannecker GE 1996 Insulin-like growth factor binding protein 2 is differentially expressed in leukaemic B- and T-cell lines. Growth Regulation 6 152-157.

Elmlinger MW, Grund R, Buck M, Wollmann HA, Feist N, Weber MM, Speer CP \& Ranke MB 1999 Limited proteolysis of the IGF binding protein-2 (IGFBP-2) by a specific serine protease activity in early breast milk. Pediatric Research 46 76-81.

Elmlinger MW, Deininger MH, Schuett BS, Meyermann R, Duffner F, Grote EH \& Ranke MB 2001 In vivo expression of insulin-like growth factor-binding protein-2 in human gliomas increases with the tumor grade. Endocrinology 142 1652-1658.

Firth SM \& Baxter RC 2002 Cellular actions of the insulin-like growth factor binding proteins. Endocrine Reviews 23 824-854.

Flyvbjerg A, Mogensen O, Mogensen B \& Nielsen OS 1997 Elevated serum insulin-like growth factor-binding protein 2 (IGFBP-2) and decreased IGFBP-3 in epithelial ovarian cancer: correlation with cancer antigen 125 and tumor-associated trypsin inhibitor. Journal of Clinical Endocrinology and Metabolism 82 2308-2313.

Frystyk J, Skjaerbaek C, Vestbo E, Fisker S \& Orskov H 1999 Circulating levels of free insulin-like growth factors in obese subjects: the impact of type 2 diabetes. Diabetes Metabolism Research and Reviews $\mathbf{1 5}$ 314-322.

Gill ZP, Perks CM, Newcomb PV \& Holly JM 1997 Insulin-like growth factor-binding protein (IGFBP-3) predisposes breast cancer cells to programmed cell death in a non-IGF-dependent manner. Journal of Biological Chemistry 272 25602-25607.

Hannigan GE, Leung-Hagesteijn C, Fitz-Gibbon L, Coppolino MG, Radeva G, Filmus J, Bell JC \& Dedhar S 1996 Regulation of cell adhesion and anchorage-dependent growth by a new beta 1integrin-linked protein kinase. Nature 379 91-96.

Hannon GJ \& Beach D 1994 p15INK4B is a potential effector of TGFbeta-induced cell cycle arrest. Nature 371 257-261.

Hjelmeland LM, Cristofolo VJ, Funk W, Rakoczy E \& Katz ML 1999 Senescence of the retinal pigment epithelium. Molecular Vision 533.

Hoeflich A, Lahm H, Blum W, Kolb H \& Wolf E 1998 Insulin-like growth factor-binding protein-2 inhibits proliferation of human embryonic kidney fibroblasts and of IGF-responsive colon carcinoma cell lines. FEBS Letters 434 329-334.

Hoeflich A, Fettscher O, Lahm H, Blum WF, Kolb HJ, Engelhardt D, Wolf E \& Weber MM 2000 Overexpression of insulin-like growth factor-binding protein-2 results in increased tumorigenic potential in Y-1 adrenocortical tumor cells. Cancer Research $\mathbf{6 0}$ 834-838.

Hoeflich A, Reisinger R, Lahm H, Kiess W, Blum WF, Kolb HJ, Weber MM \& Wolf E $2001 a$ Insulin-like growth factor-binding protein 2 in tumorigenesis: protector or promoter? Cancer Research 61 8601-8610.

Hoeflich A, Nedbal S, Blum WF, Erhard M, Lahm H, Brem G, Kolb HJ, Wanke R \& Wolf E $2001 b$ Growth inhibition in giant growth hormone transgenic mice by overexpression of insulin-like growth factor-binding protein-2. Endocrinology 142 1889-1898.

Hoeflich A, Reisinger R, Schutt BS, Elmlinger MW, Russo VC, Vargas GA, Jehle PM, Lahm H, Renner-Muller I \& Wolf E 2004 Peri/nuclear localization of intact insulin-like growth factor binding protein-2 and a distinct carboxyl-terminal IGFBP-2 fragment in vivo. Biochemical and Biophysical Research Communications 324 705-710. 
Kanety H, Madjar Y, Dagan Y, Levi J, Papa MZ, Pariente C, Goldwasser B \& Karasik A 1993 Serum insulin-like growth factor-binding protein-2 (IGFBP-2) is increased and IGFBP-3 is decreased in patients with prostate cancer: correlation with serum prostatespecific antigen. Journal of Clinical Endocrinology and Metabolism 77 229-233.

Kawano K, Kantak SS, Murai M, Yao CC \& Kramer RH 2001 Integrin alpha3betal engagement disrupts intercellular adhesion. Experimental Cell Research 262 180-196.

Keely PJ, Westwick JK, Whitehead IP, Der CJ \& Parise LV 1997 Cdc42 and Rac1 induce integrin-mediated cell motility and invasiveness through PI(3)K. Nature 390 632-636.

Li Y, Yang J, Dai C, Wu C \& Liu Y 2003 Role for integrin-linked kinase in mediating tubular epithelial to mesenchymal transition and renal interstitial fibrogenesis. Journal of Clinical Investigation 112 503-516.

Lindenbergh-Kortleve DJ, Rosato RR, van NeckJW, Nauta J, van Kleffens M, Groffen C, Zwarthoff EC \& Drop SL 1997 Gene expression of the insulin-like growth factor system during mouse kidney development. Molecular and Cellular Endocrinology 132 81-91.

Matsunaga H, Handa JT, Gelfman CM \& Hjelmeland LM 1999 The mRNA phenotype of a human RPE cell line at replicative senescence. Molecular Vision 539.

Mayo MW, Wang CY, Cogswell PC, Rogers-Graham KS, Lowe SW, Der CJ \& Baldwin AS Jr 1997 Requirement of NF-kappaB activation to suppress p53-independent apoptosis induced by oncogenic Ras. Science 278 1812-1815.

Menouny M, Binoux M \& Babajko S 1997 Role of insulin-like growth factor binding protein-2 and its limited proteolysis in neuroblastoma cell proliferation: modulation by transforming growth factorbeta and retinoic acid. Endocrinology 138 683-690.

Moore MG, Wetterau LA, Francis MJ, Peehl DM \& Cohen P 2003 Novel stimulatory role for insulin-like growth factor binding protein-2 in prostate cancer cells. International Journal of Cancer 105 14-19.

Muller HL, Oh Y, Lehrnbecher T, Blum WF \& Rosenfeld RG 1994 Insulin-like growth factor-binding protein-2 concentrations in cerebrospinal fluid and serum of children with malignant solid tumors or acute leukemia. Journal of Clinical Endocrinology and Metabolism 79 428-434.

Nobes CD \& Hall A 1995 Rho, rac and cdc42 GTPases: regulators of actin structures, cell adhesion and motility. Biochemical Society Transactions 23 456-459.

Pereira JJ, Meyer T, Docherty SE, Reid HH, Marshall J, Thompson EW, Rossjohn J \& Price JT 2004 Bimolecular interaction of insulin-like growth factor (IGF) binding protein-2 with alphavbeta3 negatively modulates IGF-I-mediated migration and tumor growth. Cancer Research 64 977-984.

Perks CM, Newcomb PV, Norman MR \& Holly JM 1999 Effect of insulin-like growth factor binding protein-1 on integrin signalling and the induction of apoptosis in human breast cancer cells. Journal of Molecular Endocrinology 22 141-150.

Prasad KV, Ao Z, Yoon Y, Wu MX, Rizk M, Jacquot S \& Schlossman SF 1997 CD27, a member of the tumor necrosis factor receptor family, induces apoptosis and binds to Siva, a proapoptotic protein. PNAS 94 6346-6351.

Ranke MB \& Elmlinger M 1997 Functional role of insulin-like growth factor binding proteins. Hormone Research 48 9-15.

Ranke MB, Maier KP, Schweizer R, Stadler B, Schleicher S, Elmlinger MW \& Flehmig B 2003 Pilot study of elevated levels of insulin-like growth factor-binding protein-2 as indicators of hepatocellular carcinoma. Hormone Research 60 174-180.

Reeve JG, Morgan J, Schwander J \& Bleehen NM 1993 Role for membrane and secreted insulin-like growth factor-binding protein2 in the regulation of insulin-like growth factor action in lung tumors. Cancer Research 53 4680-4685.
Rosenfeld RG, Pham H, Oh Y, Lamson G \& Giudice LC 1990 Identification of insulin-like growth factor-binding protein-2 (IGFBP-2) and a low molecular weight IGF-BP in human seminal plasma. Journal of Clinical Endocrinology and Metabolism 70 551-553.

Russo VC, Bach LA, Fosang AJ, Baker NL \& Werther GA 1997 Insulinlike growth factor binding protein-2 binds to cell surface proteoglycans in the rat brain olfactory bulb. Endocrinology 138 $4858-4867$.

Russo VC, Rekaris G, Baker NL, Bach LA \& Werther GA 1999 Basic fibroblast growth factor induces proteolysis of secreted and cell membrane-associated insulin-like growth factor binding protein-2 in human neuroblastoma cells. Endocrinology 140 3082-3090.

Russo VC, Schutt BS, Andaloro E, Ymer SI, Hoeflich A, Ranke MB, Bach LA \& Werther GA 2005 IGFBP-2 binding to extracellular matrix plays a critical role in neuroblastoma cell proliferation, migration and invasion. Endocrinology 146 4445-4455.

Ryan KM, Ernst MK, Rice NR \& Vousden KH 2000 Role of NF-kappaB in p53-mediated programmed cell death. Nature 404 892-897.

Sakai T, Li S, Docheva D, Grashoff C, Sakai K, Kostka G, Braun A, Pfeifer A, Yurchenco PD \& Fassler R 2003 Integrin-linked kinase (ILK) is required for polarizing the epiblast, cell adhesion, and controlling actin accumulation. Genes and Development 17 926-940.

Schutt BS, Langkamp M, Rauschnabel U, Ranke MB \& Elmlinger MW 2004 Integrin-mediated action of insulin-like growth factor binding protein-2 in tumor cells. Journal of Molecular Endocrinology 32 859-868.

Seoane J, Le HV \& Massague J 2002 Myc suppression of the p21(Cip1) Cdk inhibitor influences the outcome of the p53 response to DNA damage. Nature 419 729-734.

Shelton DN, Chang E, Whittier PS, Choi D \& Funk WD 1999 Microarray analysis of replicative senescence. Current Biology 9 939-945.

Song SW, Fuller GN, Khan A, Kong S, Shen W, Taylor E, Ramdas L, Lang FF \& Zhang W 2003 IIp45, an insulin-like growth factor binding protein 2 (IGFBP-2) binding protein, antagonizes IGFBP-2 stimulation of glioma cell invasion. PNAS 100 13970-13975.

Terrien X, Bonvin E, Corroyer S, Tabary O, Clement A \& Henrion Caude A 2005 Intracellular colocalization and interaction of insulin-like growth factor binding protein-2 with the cyclindependent kinase inhibitor p21 CIP/WAF1 during growth inhibition. Biochemical Journal 392 457-465.

Van Antwerp DJ, Martin SJ, Kafri T, Green DR \& Verma IM 1996 Suppression of TNF-alpha-induced apoptosis by NF-kappaB. Science 274 787-789.

Wang H, Shen W, Huang H, Hu L, Ramdas L, Zhou YH, Liao WS, Fuller GN \& Zhang W 2003 Insulin-like growth factor binding protein 2 enhances glioblastoma invasion by activating invasionenhancing genes. Cancer Research 63 4315-4321.

Weitzman JB, Chen A \& Hemler ME 1995 Investigation of the role of beta 1 integrins in cell-cell adhesion. Journal of Cell Science 108 3635-3644.

Yang HY, Wen YY, Chen CH, Lozano G \& Lee MH 2003 14-3-3 Sigma positively regulates p53 and suppresses tumor growth. Molecular and Cellular Biology 23 7096-7107.

Zhang Z, Vuori K, Reed JC \& Ruoslahti E 1995 The alpha 5 beta 1 integrin supports survival of cells on fibronectin and up-regulates Bcl-2 expression. PNAS 92 6161-6165.

Zumkeller W, Schwander J, Mitchell CD, Morrell DJ, Schofield PN \& Preece MA 1993 Insulin-like growth factor (IGF)-I, -II and IGF binding protein-2 (IGFBP-2) in the plasma of children with Wilms' tumour. European Journal of Cancer 29A 1973-1977.

Received in final form14 February 2006 Accepted 20 March 2006 